Economics Development Analysis Journal 9(1)(2020)

\title{
Housing Tenure Choice of Low-Income Household in Jabodetabek
}

\author{
Djoni Hartono ${ }^{\circledR}$, Reza A. Budiman², Sasmita H. Hastuti3 \\ ${ }^{1}$ Department of Economics, Faculty of Economics, Universitas Indonesia \\ ${ }^{2}$ Management Associate, Bank Permata \\ ${ }^{3}$ Research Cluster on Energy Modeling and Regional Economic Analysis
}

Article

Information

\begin{abstract}
This study aims to identify the preferences of low-income people in making housing tenure choices within the next 5 years. Each person has the right to have a place to live in. However, the options available for low-income people to own a home are limited. Therefore, information on the preferences of low-income people in purchasing houses needs to be identified so that the government can formulate effective and efficient intervention policies. A sample of 1030 samples was obtained using the stratification sampling method, of which 638 are households had rental status (taking households with the lowest level of welfare between 10-40\%) in the Regency and City. Discrete choice models were used to determine the preferences in owning a home. The study revealed that demographic variables and household characteristics variables (household size and length of stay) had consistent negative relationships with preferences for buying a house in the future. Also, the government needs to take action so that the socialization of housing policy becomes more optimal, effective and targeted. The goal of the policy socialization should be directed to newly married couples
\end{abstract}

Hisrtory of Article Received October 2019

Accepted December 2019

Pusblished February 2020

Keywords:

Housing, Household

\footnotetext{
ॠCorresponding author:

Address: Department of Economics Building, UI Depok

Campus, 16424, West Java, Indonesia

E-mail: djoni.hartono@ui.ac.id
} 


\section{INTRODUCTION}

The decision to buy a house (housing tenure choice) is a major investment choice that every household most experiences. The house represents both social and economic symbols that ultimately determine the perception of the social environment of the individuals. Thus, either owning a house or renting a house has positive and negative aspects. Therefore, the decision to own or rent a house is complex and multidimensional, involving a variety of factors such as preferences for home attributes, location and environment, and occupancy (Opoku \& Abdul-Muhmin, 2010; Wang and Li, 2016; Wu, 2010; Jim and Chen, 2007; Gupta and Malhotra, 2016). Not only that, households that want to find a solution to decisions related to homeownership immediately are also limited by at least three constraints, namely the availability of houses (purchase or rent, flow of housing vacancies); regulations from the homeowners regarding the access to housing vacancies (for example, rules related to criteria for buying or renting a house; type of payment); and the economic limitations of prospective buyers or tenants (Cirman, 2004).

In Indonesia, especially in populated large cities such as Surabaya, Bandung, Denpasar, and Jabodetabek (Jakarta, Bogor, Depok Tanggerang, and Bekasi), the limited real estate supply causes rapid growth in housing prices (Rahadi, Wiryono, \& Koesrindartoto, 2014; Bland, 2014; Delmendo, 2018). Indonesia's demographic profile, showing the demographic dividend, encourages an increase in housing demand, especially from people of productive age (under 30 years old). Consequently, the number of Indonesians willing to purchase/rent their first place of residence increases (Indonesia Investment, 2016). This aspect is coupled with the need for houses (backlog), of at least 13.5 million units, which has not been fullied so far (Indonesia Investment, 2016). The flow of urbanization is also increasing in Indonesia, along with Indonesia's transformation into an economy based on manufacturing, services, and cities. However, the benefits of urbanization can only be felt if the government provides adequate urban infrastructure, one of which is affordable and livable homes (World Bank, 2016).

On the other hand, the rapid growth in house prices is not accompanied by an adequate level of income (Rahadi, Wiryono, \& Koesrindartoto, 2014). Based on the statistics from the World Bank, Indonesia's per capita income in 2016 was still classified in the lowermiddle-income category, with figures reaching USD 3,570.3. Thus, the Indonesian population is dominated by lower-middle-income categories.

For low-middle income Indonesians, homeownership decisions are limited due to high housing costs, limited choice of location due to limited transportation systems, and the availability of decent housing in the formal market, which does not match the needs of lowincome Indonesians (Ballesteros, 2004). The availability of land for independent housing is also increasingly scarce and expensive (Ballesteros, 2004). The problem of affordability arising in the market-based housing system also causes the choice of low-income housing to be increasingly limited (Cai \& Lu, 2015). Therefore, low-income Indonesians generally turn to the informal sector to meet their needs homes, namely renting houses (Mardanugraha \& Mangunsong, 2016). However, houses for lowincome Indonesians are generally of poor quality. Besides, at the same income level, Indonesians renting houses have generally low-quality homes than those owning houses (Hoffman, Walker, J., \& Nelson, 1991).

Besides renting, another informal form commonly used is building illegal houses on state-owned land and private land, or by the river, roadside, under bridges, and along railroad tracks (Ballesteros, 2004). The informal sector is very likely to cause congestion, overcrowding, and even giving birth to slums. Slum areas resulting from the inability to buy a house have led to high costs for both the government and urban development. Aspects such as overcrowded and illegal housing result in environmental and health problems. Those issues lead to the loss of income from the housing. Although slums have been on the development 
agenda for a long time in Indonesia, the extent of slums is still quite large. In 2014, there were at least 38,341 hectares of slums. The area is also the birthplace of outbreaks of dangerous diseases, such as dengue fever, malaria, and tuberculosis (Ridho, 2014).

Low level of home purchasing ability and rising prices of lands are some of the conditions indicating the need for government intervention for solutions (Strassman, 1993). In that case, the Indonesian government formulated the provision of low-cost housing and housing assistance as a strategy to overcome the housing problem. However, the effectiveness of that strategy needs to be assessed.

The present study was carried out to determine the preferences of Indonesia capital city and its surrounding areas, Jabodetabek, in making decision related to buy house in the future (5 years). This region is choosen because it has the lowest share of houseownership (51.09\% in 2015) and also the highest housing baclog case in Indonesia (Ministry of Public Works and People's Housing, 2016). Hence, identifying people preferences in Jabodetabek may give a significant impact to solve housing problem in Indonesia.

Beside choosing a suitable region to do the analysis, this study focused in identifying preferences between different household income, especially low-income groups. Also, it tried to explain the factors influencing the decision between buying or renting houses in the present. The identification of these preferences is important so that the government can formulate effective and efficient intervention policies. Also, the identification of these preferences can be used by the private real-estate sector to capture the potential demand for low-income housing.

Next, chapter two will describe literature related to homeownership decisions, while chapter three explains the discrete choice model method for looking at people's preferences in the future. Chapter four explains the results of the study, and chapter five describes the conclusions and policy recommendations.

The decision to purchase a house is a complex process, and it can be observed from the two aspects of housing demand, namely the consumption and investment aspects (Cirman, 2004). When a household buys a house, it also gets spatial fixity, the environment (neighbors), public facilities, and tax obligations (Arnott, 1987). Not only that, homeownership decisions must also be treated as intertemporal decisions (Smith, Rosen, \& Fallis, Recent Developments in Economic Models of Housing Markets, 1988). That is because; home purchases generally begin with down-payments and mortgage loans. Loans will eventually form a household saving-pattern to pay the loan (Smith, Rosen, \& Fallis, 1988).

As a commodity, a house is generally described through its characteristics (Arnott, 1987). This is common in the housing market, where each housing agency will provide information such as a list of locations, the number of rooms, distance from the city center, and distance to public facilities (Opoku \& AbdulMuhmin, 2010; Wang and Li, 2016; Wu, 2010). Due to these characteristics, efforts in modeling the housing market are usually made through one or several characteristics of the house to define the house. On the other hand, in modeling the housing market, houses can also be described by calculating the services provided, for example, measured by the cost of rental housing.

The type of houses, to be obtained by households, also depends on the demographic characteristics of the household, the relative income, and the price difference between buying a house and renting a house (Smith, Rosen, Markandya, \& Ullmo, 1984). The income aspect can be divided into two categories, namely longterm income from workers and income from capital (Haurin, Hendershott, \& Wachter, 1997). The stability of the household demand for housing determines homeownership. If the households suspect that there will be changes in future income, marital status, and tastes, there can also be changes in housing decisions (Carliner, 1974). Also, the provision of housing is one of the 3 main decisions in households that may simultaneously occur with 2 other decisions, namely the choice of work status and household composition (e.g., marriage, number of children and so forth) (Arnott, 1987; Zheng et al., 2018). 
Therefore, the locational aspect of the house is very likely to be influenced by the work location of household members, and the number of family members occupying the house.

On the other hand, there are also house characteristics generally considered by lowincome people, both for rent and purchase. The main priority for low-income people is to get a house that is close to the work location. Next, the aspects of home quality and occupancy status considerations are considered (Panudju, 1999; Wang and Li, 2016; Wu, 2010). Besides, lowincome people generally do not pay much to the quality of the physical aspects of the house occupied if their homes can ensure their survival (Santoso, Iskandar, \& Parwoto 2002).

Generally, the biggest asset for each homeowner is the house itself. Therefore, when a household purchases a home, there are at least several motives, namely home consumption and portfolio (Arnott, 1987). After purchasing a home, the homeowner will not directly react to the changes occurring in the housing market. This reaction is due to the high transportation costs required. For example, there are costs of moving house, finding a new home, the cost of conducting sales and purchase transactions. Also, households tend to stay for a certain period after making a home purchase (Arnott, 1987).

The housing market generally has several characteristics, i.e., (1) it is imperfectly competitive, (2) regulations for building houses and buying houses are quite complex showing that there are asymmetrical information and externalities in the housing market, (3) there are institutions and developing financial instruments related to home purchases, (4) strong government intervention in the market, and (5) there are two markets in the housing market, namely the markets for rent and ownership (Arnott, 1987; Smith, Rosen, \& Fallis, 1988).

In the intertemporal framework, housing tenure choice will affect the optimal consumption path so that households will formulate current consumption to maximize lifetime utility that is limited by multiperiod budget constraints (Artle \& Varaiya, 1978; Smith, Rosen, \& Fallis, 1988). Liquidity constraints faced by households force them to reduce consumption and save money for down-payment in the home purchasing process (Artle \& Varaiya, 1978). Households will remain tenants (renter) if the utility loss from the reduction in consumption at time $t$ is smaller than the utility gained in the future when they can purchase (down-payment) a house.

On the other hand, housing tenure choice is also closely related to household characteristics, which then influence housing preferences (Cirman, 2004; Olanrewaju \& Woon, 2017). Households having high levels of mobility tend to rent a house rather than buying a house (owner-occupied) along with the high transaction cost in the purchasing process (Henderson \& Ioannides, 1983). Households with the ability to modify the residence according to their tastes will also tend to buy a house instead of renting. This condition occurs because of the positive externalities felt by the owner of the modifications made by the household (Henderson \& Ioannides, 1983). Also, the inability of the landlord to oversee the maintenance of the units lent leads to households concerned with home maintenance incentives for buying. That is because the rental rates set by the landlord will be adjusted to the average level of attention by the renters (Henderson \& Ioannides, 1983).

Apart from the aspects of household and economic characteristics, housing tenure choice is also closely related to migration, demographic and cultural factors. Based on the results of the study by Nelson (1989) in Indonesia, individuals who migrate to a new place, or live with their relatives in a new place (and then get married and rent a house) are more likely to rent a house than buying. Meanwhile, second-generation dwellers, having lived in certain cities for quite a long time, tend to be quick in making homeownership decisions. Differences in housing patterns between migrants and second-generation dwellers still occur after controlling the income variables (Nelson, 1989). This difference occurs because of three things, (1) migrants are still bound by obligations to support their families in their hometowns, (2) tenants do not plan to buy houses, and use the money to invest in other 
sectors. (3) home tenants value the flexibility offered by renting a home and withdrawing from obligations and commitments related to homeownership (Edwards, 1982).

From the demographic side, individuals will tend to rent a house if they are in transitional years, generally baccalaureate and newly married couples (Nelson, 1989). Transitional tenants imply that individuals or households wishing to have a house in the future tend to trade-off houses/units in good neighborhoods with high prices. They are urged to get out of a "no rent" state and live in quality units, allowing them to save money to buy a house (Nelson, 1989.

\section{RESEARCH METHODS}

The present research was conducted through primary data collected from surveys in Greater Jakarta (Jakarta, Bogor, Depok, Tangerang, and Bekasi) both in the Regency and City. The questionnaire covered socio-economic and demographics, affordability, and policy aspects. The sampling technique was stratification, taking households with welfare conditions, between the lowest $10-40 \%$ at each level of district/city with an income of fewer than 4 million rupiahs per month. The sampled households were also included as residents of Rental Flats (Rusunawa), rented houses, nonsubsidized private houses, and subsidized public houses.

Data collection in this study was carried out through surveyors having previously been given instructions and training related to conducting surveys. The training explained the objectives of the activity, the target respondents, and the questions in the questionnaire. Meanwhile, the survey locations in each regency/city were determined using Rusunawa housing and subsidized housing location data to identify respondents having public rents and owning public houses. Meanwhile, the data on respondents renting private houses or having non-subsidized houses was carried out through a snowball sampling in the field. Thus, the location of respondents will then be determined by the respondents preceding it. The selection of samples for houses with adjacent populations was made by finding houses within a minimum distance of 5 houses (between respondents) to avoid potential bias.

Table 1. Control variables within the questionnaire

\begin{tabular}{|c|c|}
\hline Variables & Description \\
\hline $\begin{array}{l}\text { Jobs } \\
\text { ( } 1 \text { for households having } \\
\text { jobs with stable incomes } \\
\text { and } 0 \text { for others) }\end{array}$ & Dummy \\
\hline Educational levels & Year \\
\hline Income & Rupiahs \\
\hline Age & Year \\
\hline $\begin{array}{l}\text { Living there for more } \\
\text { than } 5 \text { years } \\
\text { ( } 1 \text { for households that } \\
\text { lived there for more than } \\
5 \text { years and } 0 \text { for others) }\end{array}$ & Dummy \\
\hline $\begin{array}{l}\text { Size of the family } \\
\text { Literacy level on housing } \\
\text { sector policy } \\
\text { ( } 1 \text { for households that } \\
\text { know about at least } 1 \\
\text { housing policy) }\end{array}$ & Dummy \\
\hline
\end{tabular}

Monthly rent

Have other houses different the one being occupied

(1 for households having other houses than the one they occupy and 0 for Rupiahs (log basis 2) others)

Source : Data Processed

Of the 1030 data generated through the survey, 638 respondents had rental ownership status of houses, and only 578 respondents (or $56.1 \%$ of the total data collected) could be used to identify community housing ownership preferences in the future. This result is because field evidence showed that among respondents renting houses, middle-class people were earning more than 4 million rupiahs per month. Some of them have cars, and others still live in Rusunawa or are still leased.

Identification of future public housing ownership preferences will be carried out using a 
discrete choice model developed from the Longley (1984), Syahrial and Nazara (2006), and Wu et al. (2013). Discrete choice model is used to analyse or predict a choice from two or more alternatives which are mutually exclusive, in this study, a choice between buying or renting in the future. Mathematically, the model used in this study is as follows,

$\ln \left(\frac{P_{i}^{B R}}{P_{i}^{T S}}\right)=\alpha_{0}+\sum_{j=1}^{9} \alpha_{j} X_{j i}+\varepsilon_{i} \ldots \ldots \ldots \ldots . . . . . .(1)$
Where, $\ln \left(\frac{P_{i}^{B R}}{P_{i}^{T S}}\right)$ is the ratio between the individual probability i purchasing (own) a house in the future compared to constant renting. Meanwhile, $\mathrm{X}$ is an independent variable vector, among others, employment, education level, income, age, length of stay, family size, literacy in housing sector policies, the monthly rent, and ownership of houses other than the occupied homes. These variables are presented in Table 1.

\section{RESULTS AND DISCUSSION}

Table 2 shows the distribution of household data by the number of household members and the ownership status of the house. It revealed that a larger number of household members, the greater the chances of renting a house. For example, a household which has 5 members, prefer to choose renting (104 household) rather than buying ( 83 household). A similar pattern also occure in 6 and 9 household members (see Table 2). This might occur due to the need for more space in large-sized households to avoid overcrowding. Larger family sizes have greater housing needs, and generally, they are more responsive to prices (Quigley, 1976). There is a significant relationship between household income and homeownership status.

Table 3 reveals that households will tend to rent if their average income level is up to 5 million rupiahs per month. For example, more than $60 \%$ household with income 2.5-3 million prefer to rent a house. Meanwhile, households having income above 5 million rupiahs tend to have a house along with a better income base to make installments or down-payment.
Table 2. Household members and Ownership Status

\begin{tabular}{llll}
\hline $\begin{array}{l}\text { Family } \\
\text { members }\end{array}$ & $\begin{array}{l}\text { Ownership } \\
\text { Status } \\
\text { Owner }\end{array}$ & Renter & \\
\hline 0 & 1 & 1 & 2 \\
1 & 5 & 10 & 15 \\
2 & 21 & 56 & 77 \\
3 & 64 & 189 & 253 \\
4 & 148 & 208 & 356 \\
5 & 83 & 104 & 187 \\
6 & 36 & 43 & 79 \\
7 & 18 & 14 & 32 \\
8 & 12 & 8 & 20 \\
9 & 2 & 4 & 6 \\
10 & 0 & 1 & 1 \\
11 & 2 & 0 & 2 \\
\hline
\end{tabular}

Source: Survey's Result; Author's Calculation, 2018

Table 4 shows the level of knowledge and use of housing policy (the People's Housing Credit Kredit Perumahan Rakyat (KPR) in lowincome people. It can be observed that the level of housing policy literacy is still low, and the level of utilization is way lower, especially in Bogor region. From the sample studied, it was found that less than half of the study samples were aware of the subsidized Kredit Perumahan Rakyat (KPR) policy, amounting to $44.17 \%$. Meanwhile, the level of utilization of subsidized KPR is much lower, even almost all of the households aware of the policy do not use it (almost $80 \%$ of the total sample). The low level of subsidized housing credit usage is due to policies that are not welltargeted towards low-income people. Most of the recipients of these subsidies are generally people with income in deciles 5-8 (see Table 4).

Table 4 shows that public knowledge of the forms of government intervention in the housing market is still very low. So, it can also be said that the government policies launched have not been well socialized, both in terms of the type of policy and the form of policy intervention.

This low literacy-level makes it difficult for the policy to run effectively and reach the targets of the policy itself. 
Identifying each of variables, the age variable had a negative relationship with home purchase preferences, meaning, the older the household is, the smaller the probability of a household to change ownership status from renting to owning a house. The variable has odd ratio around 0.97 meaning that the odds of older household head buying house is 0.97 times than the younger one.

Table 3. Income Level and Ownership Status

\begin{tabular}{cccc}
\hline $\begin{array}{c}\text { Household } \\
\text { income (IDR) }\end{array}$ & $\begin{array}{c}\text { Ownership Status } \\
\text { Owner }\end{array}$ & Renter & Total \\
\hline 1 1 Millions & 25 & 32 & 57 \\
1-1.5 Millions & 28 & 37 & 65 \\
1.5-2 Millions & 45 & 78 & 123 \\
2-2.5 Millions & 42 & 68 & 110 \\
2.5-3 Millions & 58 & 130 & 188 \\
3-3.5 Millions & 75 & 119 & 194 \\
3.5-4 Millions & 62 & 97 & 159 \\
4-4.5 Millions & 24 & 59 & 83 \\
4.5-5 Millions & 9 & 10 & 19 \\
5-5.5 Millions & 6 & 2 & 8 \\
5.5-6 Millions & 6 & 2 & 8 \\
$\geq 6$ Millions & 12 & 4 & 16
\end{tabular}

Source: Survey's Result; Author's Calculation, 2018

This result is because the older the household is, the closer the household is to the final stages of its life cycle. In the final stages of the life cycle, children have started to live independently, and family size shrinks along with the need to have a home (McCarthy, 1976). Besides, households that are already in the last stages of their life cycle also generally do not make changes to housing ownership decisions, so that households continue to occupy the type of house they have purchased (whether in the form of renting or owning) (Doling, 1976; Eichholtz \& Lindenthal, 2014). Besides, these results also showed that young households tend to have a medium-term vision for owning a home. On the other hand, young low-income households also expect to buy houses, so that their expenses for residential needs can be reduced.
The same pattern was observed in the family size variable. The variable has odd ratio around 0.80 meaning that the odds of bigger household size buying house is 0.80 times than the less size household. The negative coefficient indicated that, if at present, the household is still renting a house, the increasing size of the household in the future will reduce the probability of that household to buy a house. Besides, a larger household increases the demand for larger houses or residences.

Consequently, large families need to buy or rent large dwellings too or at least have enough room for each family member. This condition is reasonable because a large family will increase household expenditure and reduce the share of household income that can be saved for house issues. Previous studies found varied results related to the influence of family size on tenure choices (Turner \& O'Neal, 1986). Carliner (1974) demonstrated that large households would increase the probability of homeownership. On the other hand, Kain and Quigley (1975) found that the probability of households owning a house decreased along with an increase in family size. The variations in the influence of these variables can be explained by the differences in income in each household. Thus, the results obtained by Carliner (1974) only apply to families with high incomes (Li, 1977). In the housing policy literacy variable, knowledge of housing policy and information (including housing prices and installment costs) had a positive effect on the probability of low-income households buying a house compared to relative future renting.

The regression results and the survey above indicated that socialization related to government intervention in the housing market needs to be held. The education variable is a crucial factor in the preferences of low-income families to continue renting or starting to buy a house. However, these variables significantly decrease when other control variables are added. The higher the level of education, the greater the probability of homeownership in the future. 
Djoni Hartono, et al/ Economics Development Analysis Journal 9 (1) (2020)

Table 4. Housing Policy Literacy and Utilization

\begin{tabular}{|c|c|c|c|c|c|c|c|c|}
\hline \multirow[t]{2}{*}{ Areas } & \multicolumn{2}{|c|}{$\begin{array}{l}\text { Understand KPR } \\
\text { Subsidies }\end{array}$} & \multicolumn{2}{|c|}{$\begin{array}{l}\text { Benefits KPR } \\
\text { Subsidies }\end{array}$} & \multicolumn{2}{|c|}{$\begin{array}{l}\text { Understand Down } \\
\text { payment assistance }\end{array}$} & \multicolumn{2}{|c|}{$\begin{array}{ll}\text { Benefits } & \text { Down } \\
\text { payment } & \\
\text { assistance } & \end{array}$} \\
\hline & Yes & No & Yes & No & Yes & No & Yes & No \\
\hline \multirow{2}{*}{$\begin{array}{l}\text { South } \\
\text { Jakarta }\end{array}$} & 17 & 13 & 0 & 17 & 3 & 27 & 0 & 3 \\
\hline & $1.65 \%$ & $1.26 \%$ & $\begin{array}{l}0.00 \\
\%\end{array}$ & $3.74 \%$ & $0.29 \%$ & $2.62 \%$ & $0.00 \%$ & $2.46 \%$ \\
\hline \multirow[b]{2}{*}{ East Jakarta } & 32 & 52 & 0 & 32 & 15 & 69 & 0 & 15 \\
\hline & $3.11 \%$ & $5.05 \%$ & $\begin{array}{l}0.00 \\
\%\end{array}$ & $7.03 \%$ & $1.46 \%$ & $6.70 \%$ & $0.00 \%$ & $12.30 \%$ \\
\hline \multirow{2}{*}{$\begin{array}{l}\text { Central } \\
\text { Jakarta }\end{array}$} & 21 & 20 & 1 & 20 & 8 & 33 & 0 & 8 \\
\hline & $2.04 \%$ & $1.94 \%$ & $\begin{array}{l}0.22 \\
\%\end{array}$ & $4.40 \%$ & $0.78 \%$ & $3.20 \%$ & $0.00 \%$ & $6.56 \%$ \\
\hline \multirow{2}{*}{$\begin{array}{l}\text { West } \\
\text { Jakarta }\end{array}$} & 16 & 18 & 0 & 16 & 1 & 33 & 0 & 1 \\
\hline & $1.55 \%$ & $1.75 \%$ & $\begin{array}{l}0.00 \\
\%\end{array}$ & $3.52 \%$ & $0.10 \%$ & $3.20 \%$ & $0.00 \%$ & $0.82 \%$ \\
\hline \multirow{2}{*}{$\begin{array}{l}\text { North } \\
\text { Jakarta }\end{array}$} & 41 & 36 & 2 & 39 & 6 & 71 & 0 & 6 \\
\hline & $3.98 \%$ & $3.50 \%$ & $\begin{array}{l}0.44 \\
\%\end{array}$ & $8.57 \%$ & $0.58 \%$ & $6.89 \%$ & $0.00 \%$ & $4.92 \%$ \\
\hline \multirow[b]{2}{*}{ Bogor } & 114 & 135 & 44 & 70 & 27 & 222 & 1 & 26 \\
\hline & $\begin{array}{l}11.07 \\
\%\end{array}$ & $13.11 \%$ & $\begin{array}{l}9.67 \\
\%\end{array}$ & $\begin{array}{l}15.38 \\
\%\end{array}$ & $2.62 \%$ & $21.55 \%$ & $0.82 \%$ & $21.31 \%$ \\
\hline \multirow[b]{2}{*}{ Bekasi } & 65 & 57 & 25 & 40 & 17 & 105 & 0 & 17 \\
\hline & $6.31 \%$ & $5.53 \%$ & $\begin{array}{l}5.49 \\
\%\end{array}$ & $8.79 \%$ & $1.65 \%$ & $10.19 \%$ & $0.00 \%$ & $13.93 \%$ \\
\hline \multirow[b]{2}{*}{ Bogor City } & 10 & 23 & 0 & 10 & 7 & 26 & 1 & 6 \\
\hline & $0.97 \%$ & $2.23 \%$ & $\begin{array}{l}0.00 \\
\%\end{array}$ & $2.20 \%$ & $0.68 \%$ & $2.52 \%$ & $0.82 \%$ & $4.92 \%$ \\
\hline \multirow[b]{2}{*}{ Bekasi City } & 28 & 42 & 2 & 26 & 10 & 60 & 0 & 10 \\
\hline & $2.72 \%$ & $4.08 \%$ & $\begin{array}{l}0.44 \\
\%\end{array}$ & $5.71 \%$ & $0.97 \%$ & $5.83 \%$ & $0.00 \%$ & $8.20 \%$ \\
\hline \multirow{2}{*}{$\begin{array}{l}\text { Kota Depok } \\
\text { City }\end{array}$} & 12 & 37 & 0 & 12 & 2 & 47 & 0 & 2 \\
\hline & $1.17 \%$ & $3.59 \%$ & $\begin{array}{l}0.00 \\
\%\end{array}$ & $2.64 \%$ & $0.19 \%$ & $4.56 \%$ & $0.00 \%$ & $1.64 \%$ \\
\hline \multirow[b]{2}{*}{ Tangerang } & 63 & 98 & 20 & 43 & 18 & 143 & 0 & 18 \\
\hline & $6.12 \%$ & $9.51 \%$ & $\begin{array}{l}4.40 \\
\%\end{array}$ & $9.45 \%$ & $1.75 \%$ & $13.88 \%$ & $0.00 \%$ & $14.75 \%$ \\
\hline \multirow{2}{*}{$\begin{array}{l}\text { Tangerang } \\
\text { city }\end{array}$} & 20 & 25 & 1 & 19 & 8 & 37 & 1 & 7 \\
\hline & $1.94 \%$ & $2.43 \%$ & $\begin{array}{l}0.22 \\
\%\end{array}$ & $4.18 \%$ & $0.78 \%$ & $3.59 \%$ & $0.82 \%$ & $5.74 \%$ \\
\hline \multirow{2}{*}{$\begin{array}{l}\text { City South } \\
\text { Tangerang }\end{array}$} & 16 & 19 & 0 & 16 & 0 & 35 & 0 & 0 \\
\hline & $1.55 \%$ & $1.84 \%$ & $\begin{array}{l}0.00 \\
\%\end{array}$ & $3.52 \%$ & $0.00 \%$ & $3.40 \%$ & $0.00 \%$ & $0.00 \%$ \\
\hline Total & 455 & 575 & 95 & 360 & 122 & 908 & 3 & 119 \\
\hline
\end{tabular}

Source: Survey's Result; Author's Calculation, 2018 
The estimation results showed that moving out and starting renting in the same (city) households having occupied rental housing in location when they begin their new stage of life. certain areas for a long period would have a They will rent while observing the market until higher probability relative to renting in the future. they find a suitable home from an economic and This condition is especially true for individuals social standpoint and then buy it (Nelson, 1989).

Table 5. Low-Income Household Preferences for Future Home Purchases

\begin{tabular}{|c|c|c|c|c|c|c|}
\hline \multirow[b]{3}{*}{ Variables } & \multicolumn{6}{|c|}{$(1=$ Buy; $0=$ Other $)$} \\
\hline & \multicolumn{2}{|c|}{ MODEL 1} & \multicolumn{2}{|c|}{ MODEL 2} & \multicolumn{2}{|c|}{ MODEL 3} \\
\hline & $\begin{array}{l}\text { Odds } \\
\text { Ratio }\end{array}$ & $\mathrm{dy} / \mathrm{dx}$ & $\begin{array}{l}\text { Odds } \\
\text { Ratio }\end{array}$ & $\mathrm{dy} / \mathrm{dx}$ & $\begin{array}{l}\text { Odds } \\
\text { Ratio }\end{array}$ & $\mathrm{dy} / \mathrm{dx}$ \\
\hline Jobs with stable incomes & 0.935 & -0.014 & 1.046 & 0.009 & 1.017 & 0.003 \\
\hline Age & $0.976^{* * *}$ & $0.005^{* * *}$ & $0.977^{* *}$ & $-0.005^{* *}$ & $0.975^{* *}$ & $-0.005^{* *}$ \\
\hline Education & $1.068^{* *}$ & $0.014^{* *}$ & $1.066^{*}$ & $0.013^{*}$ & 1.057 & 0.011 \\
\hline Size of the households & $0.847^{* *}$ & $-0.036^{* *}$ & $0.811^{* *}$ & $0.043^{* * *}$ & $0.799 * * *$ & $-\overline{0.044 * * *}$ \\
\hline Housing policy literacy & $3.063^{* * *}$ & $0.241^{* * *}$ & $2.922 * * *$ & $0.219 * * *$ & $2.289 * * *$ & $0.164^{* * *}$ \\
\hline Lived there for more than 5 years & & & $1.71^{* *}$ & $0.109^{* *}$ & $1.761^{* *}$ & $0.112^{* *}$ \\
\hline Monthly rent & & & $1.368^{* * *}$ & $0.064^{* * *}$ & $1.366^{* * *}$ & $0.062^{* * *}$ \\
\hline $\begin{array}{l}\text { Understand Information about } \\
\text { housing }\end{array}$ & & & & & $2.840^{* * *}$ & $0.206^{* * *}$ \\
\hline $\begin{array}{l}\text { Have other houses different from the } \\
\text { occupied one }\end{array}$ & & & & & 1.081 & 0.015 \\
\hline Pseudo R2 & 0.0869 & & 0.1028 & & 0.1238 & \\
\hline McFadden's Adj R2 & 0.072 & & 0.078 & & 0.093 & \\
\hline Log-likelihood & -358.189 & & -288.367 & & -281.589 & \\
\hline AIC & 1.26 & & 1.22 & & 1.2 & \\
\hline Hosmer-Lemeshow chi2 & 3.95 & & 3.93 & & 3.89 & \\
\hline Prob $>$ chi 2 & 0.8612 & & 0.8632 & & 0.8666 & \\
\hline $\mathrm{N}$ & 578 & & 486 & & 486 & \\
\hline
\end{tabular}

*Signifiant at $10 \%$

$* *$ Significant at $5 \%$

$* * *$ Significant at $1 \%$

Source: Author's Calculation, 2018

Finally, the rental cost variable had a positive relationship with the probability of households to buy a house in the future. This result means that the higher the monthly rent, the greater the tendency for households to buy a house in the future. This is natural because the high rent cost will lead smaller differences between renting and buying a house. Thus, 
buying a house is a better decision than renting.

In discrete choice model, the pseudo R2 cannot be interpreted independently or compared across datasets. However, it is valid and useful in evaluating multiple models as what we try to identify. Based on the Pseudo R2 value, it is proven that model 3 is better than the other models as it added additional variable about knowledge of housing policy which also significantly affect people's choice in housing ownership (see Table 5). Therefore, model 3 has the best result.

\section{CONCLUSION}

Housing is a primary need for every household, and the law protects its fulfillment. Meeting housing needs in Indonesia, especially for people with low-income levels, still needs to be pursued. The understanding of the factors influencing the preferences of tenure choices in these households can be one of the foundations to be used by both the government and home developers to intervene in the housing market and provide suitable housing.

Based on the estimation, the demographic variables and household characteristics had consistent and significant roles in determining tenure choices in the future. The direction of the variable also confirmed the existing theory. Other microeconomic aspects, such as education and rental costs also influenced preferences in the expected direction. Besides, the government policy aspect also had a significant influence. At least, in this aspect of the policy, the government can intervene through easing access to housing information and socialization of assistance provided by the government related to housing purchases.

Based on the results of the studies, government policy is still not popular among low-income people. Therefore, the government needs to take action so that the socialization of housing policy becomes more optimal, effective and targeted. Also, the goal of the policy socialization should be directed to newly married couples, bearing in mind that people at younger ages are likely to make future home purchases. The socialization should also be carried out for relatively unpopular housing policies, namely down payment assistance policies. To increase the robustness of the result, future studies need to add more samples and expand the analysis to other cities which also has high backlog number.

\section{REFERENCES}

Anon. 2016. Indonesia Investment. [Online] Available at: https://www.indonesiainvestments.com/id/business/industriessectors/property/item6477?

Anon. 2016. Concept Stage: National Affrodable Housing Program. World Bank.

Arnott, R.1987. Economic Theory and Housing. In: Handbook of Regional and Urban Economics. s.1.:s.n., pp. 959-988.

Artle, R. \& Varaiya, P. 1978. Life cycle consumption and homeownership. Journal of Economic Theory, 18 (1), pp. 38-58.

Ballesteros, M. M. 2004. Rental Housing for Urban Low Income Households in the Philippines, s.l.: Philippine Institute for Development Studies Paper Series (No. 2004-47).

Bland, B. 2014. Financial Times. [Online] Available at: https://www.ft.com/content /692a1104-7ec1-11e3-8642-00144feabdc0

Cai, W. \& Lu, X. 2015. Housing affordability: Beyond the income and price terms, using China as a case study. Habitat International 47, pp. 169-175.

Carliner, G. 1974. Determinants of Home Ownership. Land Economics, pp. 50(2)109-119.

Cirman, A. 2004. Housing Tenure Preferences in Societies with Marginal Rental Sectors: The Case of Slovenia. Toronto, s.n.

Delmendo, L. C. 2018. Global Property Guide. [Online] Available at: http://www.globalpropertyguide.com/Asia/i ndonesia/Price-History

Doling, J. 1976. The Family Life Cycle and Housing Choice. Urban Studies, 13 (1), pp. 55-58.

Edwards, M. A. 1982. Citie of Tenants: Renting Among the Urban Poor in Latin America. In: Urbanization in Contemporary Latin America. London: Wiley, pp. 129-158.

Eichholtz, P. and Lindenthal, T. 2014. Demographics , human capital, and the demand for housing. Journal of Housing Economics, 26, pp.19-32.

Geyer, J. 2017. Housing demand and neighborhood choice with housing vouchers. Journal of Urban Economics, 99, pp.48-61.

Gupta, V. K. \& Malhotra, G. 2016. Determining Customers' Preferences for Housing Attributes 
in India. International Journal of Housing Markets and Analysis, 9 (4), pp. 502-519.

Haurin, D. R., Hendershott, P. H. \& Wachter, S. M. 1997. Borrowing Constraits and the Tenure Chouce of Young Households. Journal of Housing Research, 8 (2), pp. 137-154.

Henderson, J. V. \& Ioannides, Y. M. 1983. A Model of Housing Tenure Choice. The American Economic Review, 73 (1), pp. 98-113.

Hoffman, M. L., Walker, C., J., S. R. \& Nelson, K. 1991. Rental Housing in Urban Indonesia. Habitat International,15 (1-2), pp. 181-208.

Jim, C.Y. and Chen, W.Y. 2007. Consumption preferences and environmental externalities:A hedonic analysis of the housing market in Guangzhou. Geoforum, 38(2), pp.414-431.

Kain, J. F. \& Quigley, J. M. 1975. Housing Markets and Racial Discrimination: A Microeconomic Analysis. National Bureau of Economic Research.

Li, M, 1977. A Logit Model of Homeownership. Econometrica, 45 (5), pp. 1081-1097.

Mardanugraha, E. \& Mangunsong, F. 2016. Housing Policy in Indonesia, Jakarta: Institute for Economic and Community Research.

McCarthy, K. F. 1976. The Household Life-Cycle and Housing Choices. Papers in Regional Science, 37 (1), pp. 55-80.

Nelson, K. W. 1989. Choices ad Opportunities: LowIncome Rental Housing in Indonesia. Review of Urban and Regional Development Studies, 1 (2), pp. 49-63.

Olanrewaju, A. L., \& Woon, T. C. 2017. An exploration of determinants of affordable housing choice. International Journal of Housing Markets and Analysis, 10 (5), pp. 703-723.

Opoku, R. A. \& Abdul-Muhmin, A. G. 2010. Housing preferences and attribute importance among low-income. Habitat International, 34 (2), pp. 219-227.

Panudju, B. 1999. City Housing Procurement with Low Income Community Participation. Bandung: Alumni.

Quigley, J. M. 1976. Housing Demand in the Short Run. In: Explorations in Economic Research, Volume 3, number 1. s.1.:NBER, pp. 76-102.
Rahadi, R. A., Wiryono, S. K. \& Koesrindartoto, D. P. 2014. Factors Influencing the Price of Housing in Indonesia. International Journal of Housing Markets and Analysis, 8 (2), pp. 169-188.

Ridho, H. 2014. Jakarta Globe. [Online] Available at: http://jakartaglobe.id/news/ ambitious- quest-slum-free-indonesia/

Santoso, J., Iskandar, B. P. \& Parwoto. 2002. Sistem Perumahan Sosial di Indonesia. Jakarta: Pusat Studi Perkotaan Universitas Indonusa Esa Unggul.

Smith, L. B., Rosen, K. T. \& Fallis, G. 1988. Recent Developments in Economic Models of Housing Markets. Journal of Economic Literature, 26 (1), pp. 29-64.

Smith, L. B., Rosen, K. T., Markandya, A. \& Ullmo, P.-A. 1984. The Demand for Housing, Household Headship Rates, and Household Formation: An International Analysis. Urban Studies, 21 (4), pp. 407-414.

Strassman, P. \& A., B. 1994. Land, income, mobility and housing: The case of Metro Manila. Urban Studies, 20 (1), pp. 267-285.

Turner, M. A. \& O'Neal, K. 1986. Household Tenure Choice: Reveiw of the Empirical Literature. Urban Institute Paper 3515-1.

Wang, D. \& Li, F. 2016. Daily Activity Space and Exposure: A Comparative Study of Hong Kong's Public and Private Housing Residents' Segregation on Daily Life. Cities, 59, pp. 48155.

Wu, F. 2010. Housing Environment Preference of Young Consumers in Guangzhou, China: Using the Analytic Hierarchy Process. Property Management, 28(3), pp. 174-192.

Yuan, C., He, X., \& Kim, Y. 2017. China Economic Review Home ownership, housing price and social security expenditure. China Economic Review, 46, pp. 290-305.

Zheng, X., Xia, Y., Hui, E. C. M., \& Zheng, L. 2018. Urban housing demand, permanent income and uncertainty: Microdata analysis of Hong Kong 's rental market. Habitat International, 74, pp. 9-17. 